\title{
Quality and sensory characteristics of soy sauces containing Astragalus membranaceus by aging period
}

\author{
Shin-Young Park ${ }^{1 *}, \mathrm{Ji}^{-M i n} \mathrm{Lim}^{2}$, Yun-Hee $\mathrm{Choi}^{2}$, Hae-Sun $\mathrm{Choi}^{1}$, Jae-Hyeon Kim ${ }^{1}$, \\ Eun-Ju Kim ${ }^{1}$, Soo-Jeong $\mathrm{Ji}^{1}$, Yeon-Jeong Jang ${ }^{1}$ \\ ${ }^{1}$ Fermentated Food Science Division, National Institute of Agricultural Science, RDA, Wanju 55365, Korea \\ ${ }^{2}$ Yeoju-si Agricultural Technology and Extension Center, Yeoju 12653, Korea
}

\section{숙성기간에 따른 황기 간장의 품질 및 관능적 특성}

\author{
박신영 ${ }^{1 *} \cdot$ 임지민 ${ }^{2} \cdot$ 최윤희 ${ }^{1} \cdot$ 최혜선 ${ }^{1} \cdot$ 김재현 ${ }^{1} \cdot$ 김은주 $^{1} \cdot$ 지수정 ${ }^{1} \cdot$ 장연정 $^{1}$ \\ 1농촌진흥청 국립농업과학원 농식품자원부 발효식품과, ${ }^{2}$ 여주시농업기술센터
}

\begin{abstract}
This study investigated changes in quality and sensory characteristics of soy sauce (Kanjang) with added Astragalus membranaceus (AK) to develop a new soy sauce product with improved sensory characteristics. The pure salinity slowly increased, but AK $\mathbf{1 0 \%}$ decreased. The pH was a constant in all samples. The soluble solid content (Brix) increased after 2 months, but AK 10\% decreased. With increased addition of Astragalus membranaceus (AM), the optical density increased after 4 months. The amino nitrogen increased in soy sauce with AK 5\%. The total free amino acid content gradually increased in soy sauce with AK 5\% aged for 6 months. As the addition of AM increased, the crude protein level decreased, but there was no difference between $\mathrm{AK} 0 \%$ and $5 \%$. The sensory tests of $\mathrm{AK}$ $5 \%$ after 6 months showed higher acceptance. According to the aging period, the acceptability of AK 5\% was the best. The results showed that soy sauce with of AK 5\% and aged for 6 months exhibits greatly enhanced quality and sensory characteristics. Therefore, it is expected to be used as a natural resources in seasoning area.
\end{abstract}

Key words : Astragalus membranaceus, soy sauce, quality characteristics, sensory characteristics, aging

\section{서 론}

간장은 음식을 조리하는데 향과 맛을 돋우기 위해 첨가 하는 조미료로서 콩에 함유된 단백질, 탄수화물 및 기타 성분들이 미생물에 의해 아미노산, 당, 단백질 peptides 및 기타 저분자 화합물로 분해됨으로서 풍부한 맛과 향이 더해 진다. 근래 들어 급속도로 산업화가 진행되면서 개량식 메 주를 이용한 간장의 공급이 증가되고 있으며 일본식 간장 및 다른 조미료에 의해 전통식품으로서의 자리를 잃어가고 있는 실정이다(1)

*Corresponding author. E-mail : soyoenj@korea.kr Phone : 82-63-238-3625, Fax : 82-63-238-3843

Received 9 September 2015; Revised 5 October 2015; Accepted 8 October 2015.

Copyright (c) The Korean Society of Food Preservation. All rights reserved.
간장은 대두 발효에 의해 isoflavone, methionine, lecitin 등 다양한 기능성 물질을 생성되며 이 생리활성 물질들은 폐경기증후군, 골다공증, 암, 심혈관계 및 동맥경화 질환 개선에 도움이 된다(2-8). 약리작용으로는 항염, 이뇨, 강장, 혈 당강하, 면역증강, 항종양, 항바이러스 작용(9-12) 등이 있으며 최근 간장으로부터 분리한 다당은 면역증진, 항염, 장관면역(13-15)에 효과가 있는 것으로 밝혀진 바가 있다.

황기(Astragalus membranaceus)는 콩과(Leguminosae)에 속하는 다년생 초본식물로 수피를 벗긴 뿌리를 건조한 것으 로 주로 한국, 중국, 일본 등에 분포해 있으며 국내는 강원도 정선, 충북 제천, 경기도 포천 등지에서 재배되고 있다(16). 한방에서 성질은 따뜻하고 맛이 달며 강장(强壯), 이뇨(利 尿), 지한(止汗) 등의 효과(17)로 십전대보탕(十全大補湯), 보중익기탕(補中益氣湯), 황기계지오물탕(黃芪桂枝五物湯), 옥병풍산(玉㞔風散) 등 처방에서 사용되고 있으며 인삼 다 음으로 많이 사용되는 보기약(補氣藥) 중 하나이다(18). 약 
리학적 성분으로는 flavonoid 화합물인 formononetin, calycosin과 saponin 계열의 astragaloside, soyasaponin 그 외 에 lipid, $\gamma$-aminobutyric acid, $\beta$-sitiosterol 등이 있다(19-22). 최근 한약재 등 기능성 소재 첨가(23-25)를 통해 장류의 맛과 효능을 증진시키는 연구가 진행되고 있으며 원래의 식품이나 한약재보다 기능이 증가되고 식품으로서 부작용 이 없고 장기적으로 섭취가 가능하기 때문에 관련 연구가 더욱 활기를 띄게 될 전망이다.

따라서 본 연구에서는 황기 첨가를 통해 풍미를 개선시 키고 기호성을 향상시킬 수 있는 간장 제품을 개발하고자 발효기간에 따른 황기 간장의 품질 및 관능적 특성을 조사 하여 가능성을 검토하였다.

\section{재료 및 방법}

\section{실험재료}

본 실험에서 사용된 대두는 경남 함양산 백태(Glycine $\max$ L.)이며, 황기는 경 동시장 (Hanbangchun, Seoul, Korea) 에서 충북 제천산을 구입하여 100 mesh 입도로 분쇄하여 사용하였다.

\section{간장제조}

간장은 메주 제조 시 황기 첨가량에 따라 제조하였다. 메주 제조는 물에 불린 콩 각 $2 \mathrm{~kg}$ 를 8 시간 침지시키고 6시간 증자 후 이를 마쇄하고 분말 황기는 각각 $5 \%, 10 \%$ 와 황국 $1 \%$ (Chungmu Fermentation, Ulsan, Korea)를 첨가한 다음 이를 충분히 혼합하여 $15 \times 11 \times 6 \mathrm{~cm}$ 로 성형하였다. 성형 후 2 일간 겉 말림을 하였으며 온도는 $25 ~ 30^{\circ} \mathrm{C}$, 상대습 도 80 90\% 조건의 발효실에서 한 달간 발효시켜 제조하였 다. 간장의 제조는 물 $18 \mathrm{~L}$ 에 소금 $7 \mathrm{~kg}$ 를 용해한 소금물(염 도 $20 \%$ )에 각각 성형하여 건조된 메주를 모두 담금하여 6 개월간 발효숙성 시켰다. 이때 사용된 소금은 시판 천일염 이며 물은 정수된 것을 이용하였다. 6개월 숙성기간 동안 1 개월 간격으로 채취하여 $3,000 \mathrm{rpm}$ 에서 30 분간 원심분리 (Supra 25 K, Hanil Science Industrial, Incheon, Korea) 한 후 상등액을 취하여 $4{ }^{\circ} \mathrm{C}$ 에 보관하며 기간별 품질 특성을 알아보았다.

\section{식염 측정}

식염은 $\mathrm{Mohr}$ 법(26)에 따라 간장 $5 \mathrm{~mL}$ 를 $250 \mathrm{~mL}$ 로 희석 하고, 이 중 $10 \mathrm{~mL}$ 를 삼각플라스크에 취하여 $5 \% \mathrm{~K}_{2} \mathrm{CrO}_{4}$ $1 \mathrm{~mL}$ 를 넣고 $0.1 \mathrm{~N} \mathrm{AgNO}_{3}$ 을 가하여 적갈색이 15 초간 사라 지지 않을 때까지 소요된 질산은 용액의 양으로 산출하였다.

\section{$\mathrm{pH}$ 및 가용성 고형분 측정}

간장의 $\mathrm{pH}$ 는 $\mathrm{pH}$ meter(HM-30P, DKK-TOA, Tokyo,
$\mathrm{Japan}$ )로 3 회 측정하였다. 가용성 고형분 함량은 간장 1 $\mathrm{g}$ 에 증류수 $10 \mathrm{~mL}$ 를 가하여 균질화한 다음 $3,000 \mathrm{rpm}$ 에서 10 분간 원심분리 하여 얻은 상층액을 당도계(ATAGO $\mathrm{N}-2 \mathrm{E}$, Atago, Tokyo, Japan)를 이용하여 측정하였다.

\section{갈색도 측정}

갈색도는 Yilmaz와 Toledo의 방법(27)을 변형하여 측정 하였다. 즉, 시료 $1 \mathrm{~g}$ 을 증류수 $40 \mathrm{~mL}$ 와 진탕하고 $10 \%$ trichloroacetic acid $40 \mathrm{~mL}$ 를 첨가한 후 2시간동안 반응 시킨 다. 그 후 원심분리기(MEGA2100, Hanil, Seoul, Korea)를 이용하여 $4,000 \mathrm{rpm}$ 에서 20 분간 원심분리 후 상등액만 취해 microplatereader(Molecular Devices, Sunnyvale, CA, USA) 를 이용하여 $420 \mathrm{~nm}$ 에서 흡광도를 측정하였다.

\section{조단백질 측정}

조단백질의 함량은 Kjeldahl법(28)으로 측정하였다. 즉, 시료 $0.3 \mathrm{~g}$ 을 정량하여 Kjeldahl 플라스크에 취하고, 여기에 비등석과 $\mathrm{HgO}$ 촉매, 진한 $\mathrm{H}_{2} \mathrm{SO}_{4} 10 \mathrm{~mL}$ 를 가하고 서서히 가열하여 분해하였다. 시료 분해액을 실온으로 냉각시킨 후 증류수 $30 \mathrm{~mL}$ 를 가하고, $\mathrm{NaOH}$ 용액을 넣어 Kjeldahl 증류장치에서 가열하여 증류되어 나오는 암모니아를 $\mathrm{H}_{2} \mathrm{BO}_{3}$ 가 들어있는 수기에 포집시켰다. 이 때 증류액이 250 $\mathrm{mL}$ 정도가 되면 암모니아는 거의 추출되어 나온 것으로 보았으며, 증류가 끝나면 청록색의 수용액이 회백색이 될 때 까지 $0.1 \mathrm{~N} \mathrm{HCl}$ 용액으로 적정하여 아래 식에 따라 조단 백질 함량으로 환산하였다.

$$
\text { 조단백질 }(\%)=\frac{0.014 \times\left(V_{1}-V_{0}\right) \times F \times D \times N}{S} \times 100
$$

$\mathrm{V}_{1}$ : 본 시험의 $0.1 \mathrm{~N} \mathrm{HCl}$ 용액의 적정 소비량 $(\mathrm{mL})$

$\mathrm{V}_{0}$ : 공 시험의 $0.1 \mathrm{~N} \mathrm{HCl}$ 용액의 적정 소비량 $(\mathrm{mL})$

$\mathrm{F}$ : $0.1 \mathrm{~N} \mathrm{HCl}$ 표준용액의 역가

$\mathrm{D}$ : 희석배수

$\mathrm{N}$ : 질소 계수(6.25)

$\mathrm{S}$ : 시료의 채취량 $(\mathrm{g})$

\section{아미노태 질소 측정}

간장의 아미노태 질소는 Formol 적정법(29)으로 측정하 였다. 간장 $10 \mathrm{~mL}$ 에 증류수 $90 \mathrm{~mL}$ 를 가한 후 30 분 동안 교반하였다. $1 \%$ 페놀프탈레인 지시약을 2 3 방울 가하고 $0.1 \mathrm{~N} \mathrm{NaOH}$ 용액으로 $\mathrm{pH} 4.8$ 까지 맞추고 $35 \%$ formalin 용액을 $20 \mathrm{~mL}$ 가하고 $0.1 \mathrm{~N} \mathrm{NaOH}$ 용액으로 적정하여 소비 된 $\mathrm{NaOH}$ 의 양을 계산하여 아미노태 질소 함량을 구하였다.

\section{유리 아미노산 측정}

간장 시료 $2 \mathrm{~mL}$ 에 3차 증류수 $50 \mathrm{~mL}$ 첨가하여 초음파 (WUC-D22H, Daehan Scientific Co., Ltd., Wonju, Korea) 
처리로 20 분간 추출과정을 거친 후 $3,000 \mathrm{rpm}$ 에서 10 분간 원심분리하여 $2 \mathrm{~mL}$ 의 상등액을 취하였다. 상등액에 $5 \%$ trichloroacetic acid(TCA) $2 \mathrm{~mL}$ 를 넣고, $10,000 \mathrm{rpm}$ 에서 10 분간 원심분리 한 후 $0.02 \mathrm{~N} \mathrm{HCl}$ 로 희석해 $0.2 \mu \mathrm{m}$ syringe filter로 여과하여 아미노산 자동분석기(L-8900, Hitachi High-Technologies, Tokyo, Japan)로 분석하였다.

\section{관능검사}

황기 첨가 후 6 개월간 숙성한 간장을 2 개월 간격으로 기호도를 평가하였다. 관능검사는 15 명의 패널로 구성되었 으며 향, 짠맛, 구수한맛, 단맛, 쓴맛 및 전체 기호도에 대한 9점 척도법(1:아주 나쁨, 3:나쁨, 5:보통, 7:좋음, 9:아주 좋 음)으로 간장 시료를 패널에게 제공하고 적당량을 시식하 게 하여 평가하였다.

\section{통계처리}

본 실험은 독립적으로 3 회 이상 반복 실험을 실시하였다. 실험군 간의 통계적 유의성 검증을 위해 SPSS(17.0, SPSS Inc., Chicago, IL, USA)를 이용하여 분산분석과 Duncan's multiple range test를 실시하였다.

\section{결과 및 고찰}

\section{식 염}

발효 기간에 따른 황기간장의 식염은 Fig. 1과 같다. 황기 간장의 식염은 실험군 모두에서 유의적인 차이를 보이지 않았으며, 황기 첨가 $0 \%$ 와 5\%는 염도가 20 22\%였으며 황기 첨가 $10 \%$ 는 염도가 $20 \%$ 로 약간 낮아지는 경향을 보였 다. 이는 숙성기간이 길어질수록 간장 내의 수분 증발로 상대적으로 식염도가 증가된다는 보고가 있으며 $(1,30,31)$,

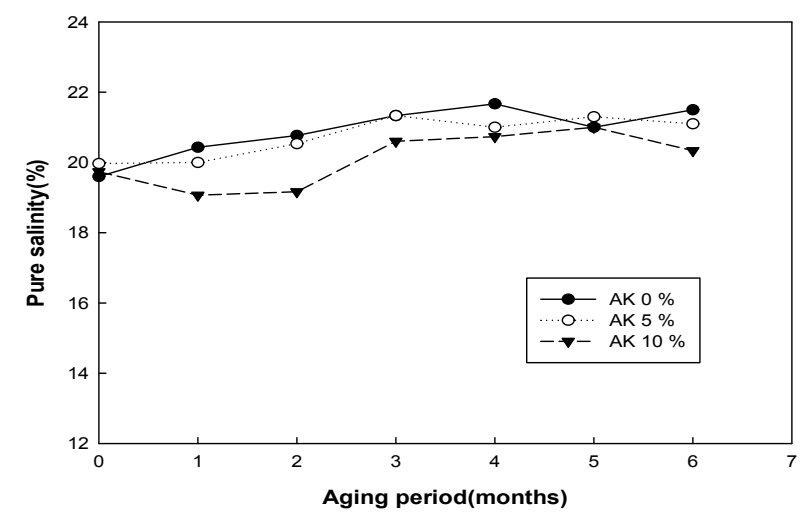

Fig. 1. Changes in the pure salt content of soy sauce containing Astragalus membranaceus during aging for 6 months.

AK 0\%, soy sauce (Kanjang) containing 0\% Astragalus membranaceus, AK 5\%, soy sauce (Kanjang) containing 5\% Astragalus membranaceus, AK 10\%, soy sauce (Kanjang) containing $10 \%$ Astragalus membranaceus.
또한 황기 첨가량이 많아질수록 염도가 낮아지는 경향을 보였는데 이는 삼백초와 어성초 등 약용식물 첨가에 의해 어간장의 염도가 다소 낮아진다는 보고와 일치하였다(32). 황기 첨가량이 많을수록 염을 흡수하기 때문인 것으로 사료 된다.

\section{$\mathrm{pH}$ 및 가용성 고형분}

숙성 기간에 따른 황기간장의 $\mathrm{pH}$ 와 가용성 고형분 함량 은 Fig. 2,3과 같다. 본 실험에서 실험군 모두 숙성 기간에 따른 $\mathrm{pH}$ 변화는 뚜렷하지 않았다. 가용성 고형분은 황기 $10 \%$ 첨가된 간장이 1 개월까지는 높았으나 2개월부터 황기 를 $5 \%$ 이하로 첨가한 간장에서 크게 증가되었으며 3개월 이후 일정하게 유지되었다. 그러나 황기를 $10 \%$ 첨가한 간

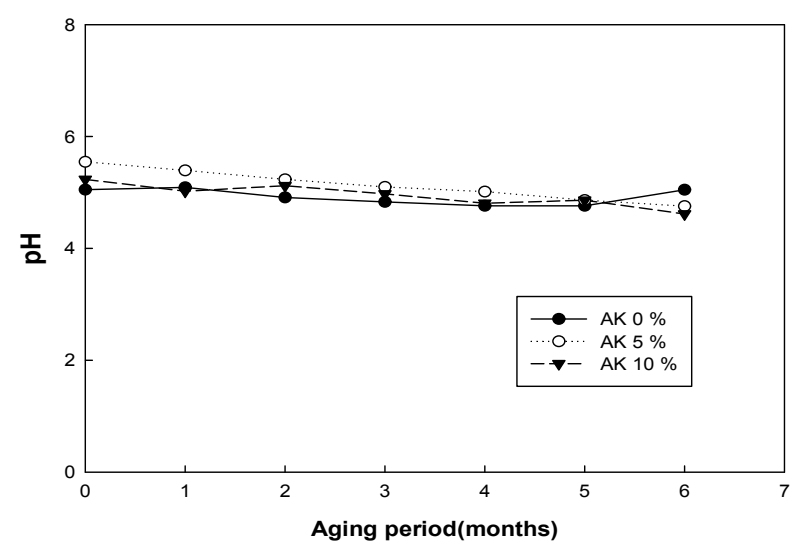

Fig. 2. Changes in the $\mathrm{pH}$ contents of soy sauce containing Astragalus membranaceus during aging for 6 months.

AK 0\%, soy sauce (Kanjang) containing 0\% Astragalus membranaceus, AK 5\%, soy sauce (Kanjang) containing 5\% Astragalus membranaceus, AK 10\%, soy sauce (Kanjang) containing $10 \%$ Astragalus membranaceus

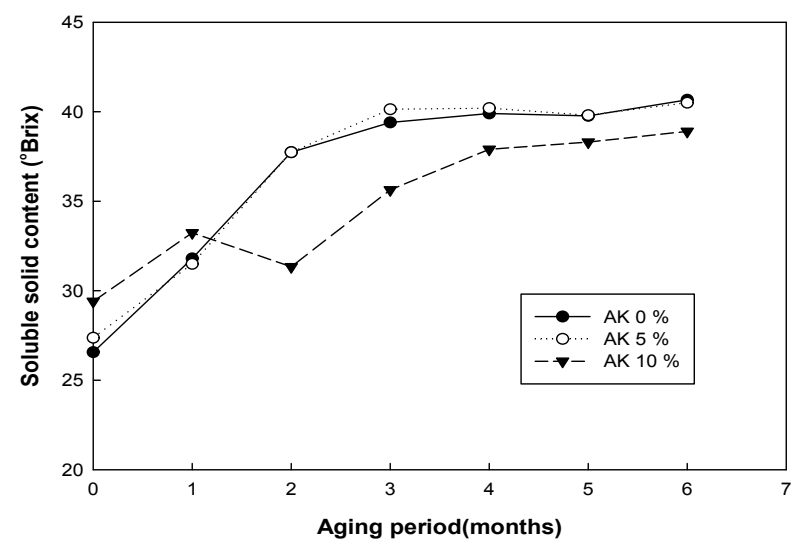

Fig. 3. Changes in the soluble solid content of soy sauce containing Astragalus membranaceus during aging for 6 months.

AK 0\%, soy sauce (Kanjang) containing 0\% Astragalus membranaceus, AK 5\%, soy sauce (Kanjang) containing 5\% Astragalus membranaceus, AK 10\%, soy sauce (Kanjang) containing 10\% Astragalus membranaceus. 
장은 그에 비해 낮은 경향을 보였는데 황기 첨가량이 많아 질수록 초기의 가용성 고형분에 영향을 주는 것으로 사료된 다. 이러한 결과는 메주나 간장에 존재하는 당류와 황기에 함유된 당이 발효미생물의 기질로 이용되어 가용성 고형분 이 감소되는 것으로 사료된다(33).

\section{갈색도}

황기간장의 갈색도 변화는 Fig. 4와 같다. 황기 무첨가 및 $5 \%$ 첨가 간장은 5 개월까지 갈색도가 증가되는 경향을 보였으며 그에 반해 $10 \%$ 첨가 황기 간장도 갈색도가 증가 되었으나 4개월 이후 무첨가 간장과 비슷한 수준의 색을 유지하는 것으로 나타났다. 이 결과는 약재 첨가 개량식 간장의 갈색화가 보통 대두로 제조한 간장의 경우 숙성기간 이 길어질수록 갈색화가 일어난다는 보고와 거의 일치하였 으며(34), 이는 황기 첨가량이 증가될수록 갈색화가 일어나 지만 일정한 숙성 기간 이후 더 이상 진행되지 않는다. 황기 $10 \%$ 간장의 숙성 4 개월부터 갈색화가 더디게 진행되어 장기간 유통 시 긍정적인 영향이 미칠 것으로 사료된다.

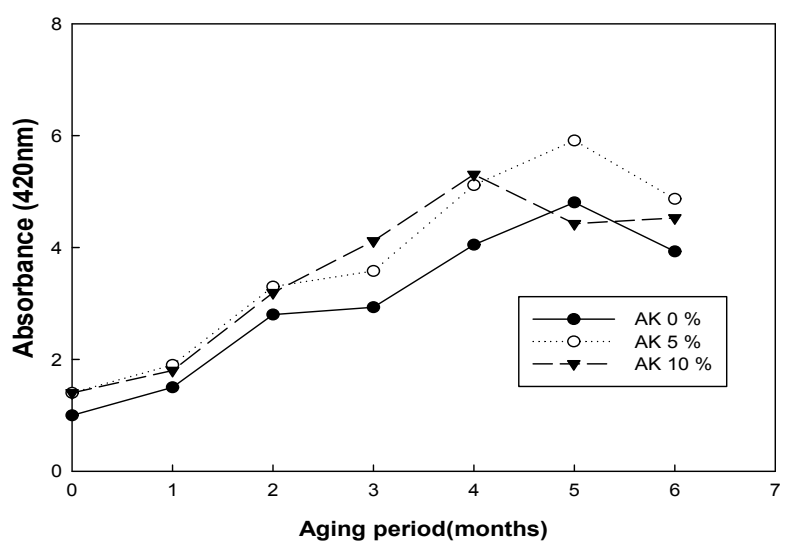

Fig. 4. Changes in the optical density of soy sauce containing Astragalus membranaceus during aging for 6 months.

AK 0\%, soy sauce (Kanjang) containing 0\% Astragalus membranaceus, AK 5\%, soy sauce (Kanjang) containing 5\% Astragalus membranaceus, AK 10\%, soy sauce (Kanjang) containing 10\% Astragalus membranaceus.

\section{조단백질}

황기간장의 조단백질 함량은 Fig. 5와 같다. 황기 무첨가 와 $5 \%$ 첨가 간장은 숙성 기간이 지남에 따라 증가되는 경향을 보였지만 황기 $10 \%$ 첨가 간장은 그에 비해 차이가 거의 없었으며 4 개월 이후 증가되었지만 두 첨가 간장에 비해 미미하였다(24). 이는 황기의 첨가량이 증가할수록 단백질 분해 효소인 protease 활성이 증가되고 이로 인하여 아미노산 생성량이 증가되어 풍미를 더한다는 연구 결과가 보고(23)된 바 있으며 그에 대비해 조단백질 함량이 낮은 것으로 사료된다. 그리고 일반적으로 전통간장의 조단백질 함량은 $7.7 \%$ 로 보고(35) 된 바 있으며 약용식물 추출물을
첨가한 간장에서는 조단백질 함량이 8.0 8.4\%(4)로 황기 무첨가 및 $5 \%$ 첨가 간장에서 비슷한 경향을 보였다. 황기 첨가량이 $10 \%$ 이상일 때 조단백질 함량이 다소 낮은 증가 율을 보였는데 이는 아미노태 질소가 낮은 것과 관련이 있는 것으로 판단된다.

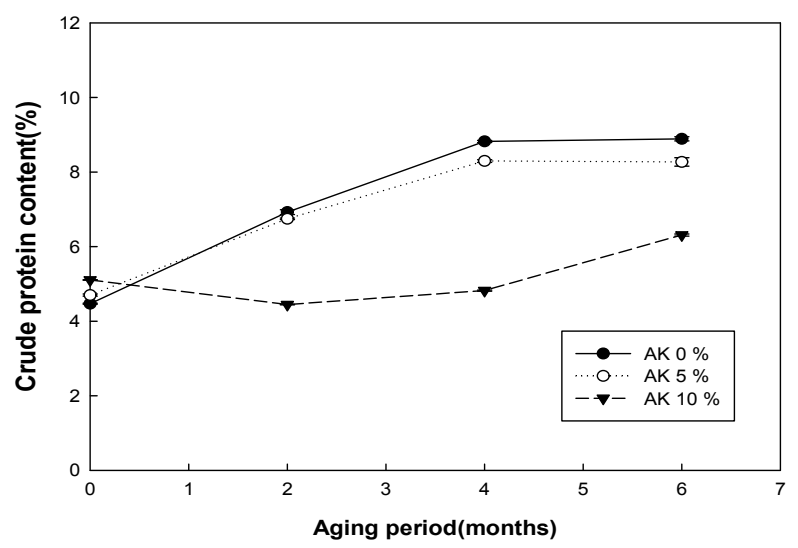

Fig. 5. Changes in the reducing crude protein content of soy sauce containing Astragalus membranaceus during aging for 6 months.

AK 0\%, soy sauce (Kanjang) containing 0\% Astragalus membranaceus, AK 5\%, soy sauce (Kanjang) containing 5\% Astragalus membranaceus, AK 10\%, soy sauce (Kanjang) containing $10 \%$ Astragalus membranaceus.

\section{아미노태 질소}

아미노태 질소는 발효식품의 숙성 정도와 보존기간 품질 의 지표가 되는 성분으로 단백질이 효소에 의해 가수분해 되어 아미노산을 생성하며 아미노태 질소가 높은 간장은 관능적으로 좋은 것으로 평가되고 있다(36). 본 실험에서 황기 첨가 간장의 아미노태 질소 함량 변화는 Fig. 6 에 나타 내었다. 황기 첨가 간장은 숙성 시간이 길어짐에 따라 계속

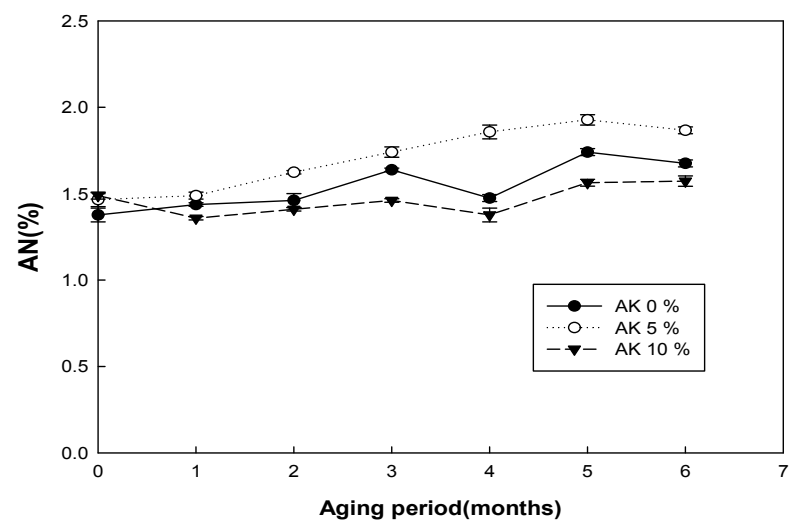

Fig. 6. Changes in the amino-type nitrogen(AN) content of soy sauce containing Astragalus membranaceus during aging for 6 months.

AK 0\%, soy sauce (Kanjang) containing 0\% Astragalus membranaceus, AK 5\%, soy sauce (Kanjang) containing 5\% Astragalus membranaceus, AK 10\%, soy sauce (Kanjang) containing 10\% Astragalus membranaceus. 
증가하는 양상을 보였으며 이는 개량식 메주에 첨가된 황국 균에 의해 생성된 단백질 가수분해 효소들의 작용으로 작은 펩타이드로 분해되었기 때문이라 생각된다. 그리고 황기 $5 \%$ 첨가 간장의 아미노태 질소 함량이 가장 높았으며 간장 이 숙성될수록 아미노태 질소함량이 증가 되었다는(29) 결 과와 일치 하였다. 또한 황기 $5 \%$ 첨가 간장의 숙성 6 개월 때 유리 아미노산 중 glutamic acid, glycine, serine을 다량 함유하고 있으며 이는 발효기간에 따라 황국(Aspergilus oryzae) 등 미생물에 의해 분해되어 아미노태 질소에 영향 을 미치는 것으로 판단된다. 반면 무첨가 및 $10 \%$ 첨가 황기 간장은 낮은 경향을 보였으며 유의적인 차이는 나타나 지 않았다.

\section{유리 아미노산}

유리 아미노산을 amino acid autoanalyzer로 분석한 결과 는 Table 1 과 같다. 시험구에 따라 차이가 있으나 histidine, serine, arginine 등 17종 아미노산이 검출 되었다. 유리 아미 노산 총량은 발효기간이 경과함에 따라 증가하는 경향이 있었으며 무첨가 간장과 황기 $10 \%$ 첨가 간장에서는 5 개월
때 각각 1,101 및 $1,281 \mathrm{mg} / 100 \mathrm{~mL}$ 였으며 황기 $5 \%$ 첨가 간장은 6 개월 때 $2,726 \mathrm{mg} / 100 \mathrm{~mL}$ 로 함량이 가장 높았다. 아미노태질소와 조단백질 함량이 황기 $5 \%$ 첨가 간장에서 6 개월 때 가장 높게 나타난 것은 유리 아미노산 중 glutamic acid, glycine, serine 등이 타 시험구 보다 현저히 높은데 그 원인이 있다고 본다.

콩, 메주 및 재래식 간장에서 glutamic acid 함량이 높으며 본 실험결과도 같은 결과를 보였다(37-40). 콩을 원료로 하 는 간장의 유리 아미노산이 숙성 기간의 경과함에 따라 증가되며 단맛(41)과 구수한 맛(42)의 주성분인 glutamic acid, glycine, serine 등 함량이 높은 것으로 보아 전통간장은 최소 5 개월 이상 숙성시키는 것이 바람직하다고 보며 황기 $5 \%$ 첨가 간장은 6 개월 숙성 시 가장 좋은 것으로 나타났다. 또한 황기에는 glycine, serine 등 다양한 아미노산을 함유하 고 있으며(43) 미생물에 의해 분해되어 아미노산 함량에 영향을 미치는 것으로 판단된다.

\section{관능평가}

황기 간장의 숙성 기간별 관능평가는 9점 척도법으로

Table 1. Free amino acid contents of soy sauce containing Astragalus membranaceus during aging for 6 months

(Unit : $\mathrm{mg} / 100 \mathrm{~mL}$ )

\begin{tabular}{|c|c|c|c|c|c|c|c|c|c|c|c|c|c|c|c|c|c|c|c|c|c|}
\hline \multirow{3}{*}{ Free amino acids } & \multicolumn{21}{|c|}{ Astragalus membranaceus } \\
\hline & \multicolumn{7}{|c|}{$0 \%$} & \multicolumn{7}{|c|}{$5 \%$} & \multicolumn{7}{|c|}{$10 \%$} \\
\hline & $0 \mathrm{M}^{2)}$ & $1 \mathrm{M}$ & $2 \mathrm{M}$ & $3 \mathrm{M}$ & $4 \mathrm{M}$ & $5 \mathrm{M}$ & $6 \mathrm{M}$ & $0 \mathrm{M}$ & $1 \mathrm{M}$ & $2 \mathrm{M}$ & $3 \mathrm{M}$ & $4 \mathrm{M}$ & $5 \mathrm{M}$ & $6 \mathrm{M}$ & $0 \mathrm{M}$ & $1 \mathrm{M}$ & $2 \mathrm{M}$ & $3 \mathrm{M}$ & $4 \mathrm{M}$ & $5 \mathrm{M}$ & $6 \mathrm{M}$ \\
\hline Histidine & 7 & 8 & 9 & 8 & 8 & 30 & 28 & 5 & 6 & 8 & 8 & 7 & 24 & 86 & 5 & 4 & 7 & 5 & 7 & 36 & 38 \\
\hline Serine & 9 & 20 & 27 & 24 & 24 & 56 & 40 & 14 & 17 & 24 & 24 & 24 & 86 & 233 & 14 & 11 & 14 & 7 & 15 & 102 & 56 \\
\hline Arginine & 13 & 13 & 18 & 1 & 1 & $\mathrm{ND}^{3)}$ & ND & 1 & 2 & 2 & 2 & 2 & $\mathrm{ND}$ & 26 & 19 & 16 & 15 & 13 & 16 & 59 & 41 \\
\hline Glycine & 10 & 11 & 14 & 15 & 14 & 59 & 53 & 9 & 12 & 16 & 29 & 16 & 96 & 233 & 7 & 6 & 10 & 9 & 10 & 102 & 71 \\
\hline Aspartic acid & 24 & 26 & 37 & 33 & 32 & 72 & 40 & 21 & 25 & 38 & 35 & 37 & 68 & 156 & 17 & 15 & 22 & 9 & 23 & 62 & 32 \\
\hline Glutamic acid & 62 & 64 & 88 & 88 & 84 & 250 & 159 & 47 & 62 & 89 & 84 & 82 & 204 & 472 & 47 & 39 & 61 & 37 & 67 & 196 & 101 \\
\hline Threonine & 14 & 15 & 21 & 20 & 19 & 48 & 38 & 11 & 14 & 20 & 19 & 19 & 57 & 178 & 14 & 11 & 14 & 9 & 13 & 63 & 49 \\
\hline Alanine & 18 & 119 & 26 & 28 & 27 & 71 & 43 & 17 & 20 & 29 & 29 & 29 & 101 & 179 & 14 & 12 & 14 & 9 & 15 & 90 & 35 \\
\hline Proline & 12 & 13 & 18 & 18 & 18 & 60 & 48 & 6 & 9 & 14 & 14 & 14 & 65 & 107 & 7 & 8 & 7 & 4 & 8 & 71 & 36 \\
\hline Cystenine & 1 & 2 & 2 & 2 & 1 & 20 & 16 & 2 & 2 & 3 & 2 & 2 & 21 & 23 & 7 & 2 & 1 & 1 & $\mathrm{ND}$ & 21 & 13 \\
\hline Lysine & 27 & 28 & 37 & 33 & 31 & 63 & 15 & 19 & 23 & 32 & 32 & 32 & 54 & 67 & 22 & 19 & 28 & 20 & 30 & 60 & 10 \\
\hline Tyrosine & 15 & 17 & 21 & 13 & 17 & 51 & 63 & 10 & 12 & 18 & 10 & 16 & 36 & 129 & 10 & 8 & 12 & 11 & 13 & 67 & 76 \\
\hline Methionine & 6 & 5 & 6 & 5 & 5 & 19 & 14 & 3 & 4 & 6 & 5 & 5 & 12 & 28 & 6 & 4 & 3 & 3 & 2 & 16 & 12 \\
\hline Valine & 20 & 21 & 27 & 28 & 28 & 80 & 63 & 15 & 18 & 26 & 27 & 27 & 109 & 195 & 11 & 12 & 17 & 15 & 17 & 89 & 52 \\
\hline Isoleucine & 18 & 19 & 26 & 27 & 27 & 57 & 46 & 15 & 18 & 27 & 28 & 28 & 71 & 143 & 13 & 11 & 15 & 14 & 16 & 62 & 44 \\
\hline Leucine & 28 & 30 & 40 & 37 & 36 & 94 & 77 & 21 & 25 & 38 & 37 & 36 & 111 & 222 & 22 & 18 & 23 & 19 & 24 & 106 & 74 \\
\hline Phenylalanine & 19 & 21 & 27 & 24 & 24 & 71 & 89 & 16 & 19 & 27 & 26 & 26 & 83 & 248 & 15 & 13 & 15 & 13 & 16 & 81 & 97 \\
\hline Total amino acid & 303 & 431 & 445 & 402 & 397 & 1101 & 831 & 230 & 286 & 417 & 408 & 402 & 1198 & 2726 & 248 & 208 & 278 & 197 & 290 & 1281 & 835 \\
\hline
\end{tabular}

${ }^{1)} \mathrm{AK} 0 \%$, soy sauce (Kanjang) containing 0\% Astragalus membranaceus, AK 5\%, soy sauce (Kanjang) containing 5\% Astragalus membranaceus, AK 10\%, soy sauce (Kanjang) containing $10 \%$ Astragalus membranaceus.

${ }^{2)}$ During aging months.

${ }^{3)} \mathrm{ND}$, not detected. 
조사하였으며 결과는 Table 2 와 같다. 황기 첨가량이 많을 수록 황기 특유의 맛으로 인해 거부감을 느끼는 것으로 나타났으며 황기 $5 \%$ 첨가 간장은 숙성 기간이 지남에 따라 구수한맛, 단맛, 전체 기호도에서 모두 상승이 되었으며 황기 $10 \%$ 첨가 간장은 숙성 초기 2 개월부터 4 개월까지 기호도가 우수하였으며 그 이후 점차 기호도가 감소되었 다. 이는 첨가제인 황기를 적절히 사용하였을 때 약재 특유 의 감칠맛이 간장의 짠맛을 저감시켜 영향을 준 것으로 사료된다.
보지 않았다. 유리 아미노산 측정결과 황기 $5 \%$ 첨가 간장의 6 개월 때가 가장 높은 함량을 나타내었다. 관능평가에서는 황기 $5 \%$ 첨가 간장의 숙성기간이 증가됨에 따라 기호도가 점차 향상되었으며 이러한 결과를 미루어 보아 황기 $5 \%$ 첨가 간장이 황기 무첨가 간장에 비해 염도가 낮고 아미노 태질소가 높으며 기호도는 6개월 때가 가장 우수하였으며, 풍미가 좋은 간장으로의 활용 가능성이 있음을 제시하였 다.

Table 2. Sensory characteristics of soy sauce containing Astragalus membranaceus during aging for 6 monts

\begin{tabular}{|c|c|c|c|c|c|c|c|c|}
\hline \multirow{2}{*}{\multicolumn{2}{|c|}{ Soy sauce ${ }^{1)}$}} & \multicolumn{7}{|c|}{ Sensory attribute } \\
\hline & & Color & Flavor & Tasty & Salty & Sweet & Soury & Total accept \\
\hline \multirow{3}{*}{$0 \mathrm{M}^{2)}$} & $\mathrm{AK} 0 \%$ & $5.0^{\mathrm{a} 3)}$ & $4.9^{\mathrm{a}}$ & 5.3 & $4.9^{\mathrm{a}}$ & 5.2 & $4.8^{\mathrm{a}}$ & $5.0^{\mathrm{a}}$ \\
\hline & AK 5\% & $6.0^{\mathrm{b}}$ & $4.9^{\mathrm{a}}$ & 5.3 & $5.2^{\mathrm{ab}}$ & 5.1 & $5.3^{\mathrm{b}}$ & $5.3^{\mathrm{ab}}$ \\
\hline & AK $10 \%$ & $5.5^{\mathrm{ab}}$ & $5.7^{\mathrm{b}}$ & 5.4 & $5.6^{b}$ & 5.4 & $5.2^{\mathrm{b}}$ & $5.8^{\mathrm{b}}$ \\
\hline \multirow{3}{*}{$2 \mathrm{M}$} & $\mathrm{AK} 0 \%$ & $5.3^{\mathrm{a}}$ & 5.5 & 5.8 & $4.3^{\mathrm{a}}$ & $4.8^{\mathrm{a}}$ & $4.3^{\mathrm{a}}$ & $5.5^{\mathrm{a}}$ \\
\hline & AK 5\% & $5.9^{b}$ & 5.2 & 5.5 & $5.4^{\mathrm{b}}$ & $5.5^{\mathrm{b}}$ & $4.9^{\mathrm{ab}}$ & $5.6^{\mathrm{a}}$ \\
\hline & AK $10 \%$ & $6.1^{b}$ & 5.6 & 5.7 & $5.3^{b}$ & $5.6^{b}$ & $5.4^{\mathrm{b}}$ & $6.1^{b}$ \\
\hline \multirow{3}{*}{$4 \mathrm{M}$} & $\mathrm{AK} 0 \%$ & $6.2^{\mathrm{ab}}$ & $5.1^{\mathrm{a}}$ & $5.5^{\mathrm{a}}$ & $5.0^{\mathrm{a}}$ & $5.3^{\mathrm{a}}$ & $4.3^{\mathrm{a}}$ & $5.1^{\mathrm{a}}$ \\
\hline & AK 5\% & $5.9^{\mathrm{a}}$ & $5.2^{\mathrm{a}}$ & $5.9^{\mathrm{b}}$ & $5.0^{\mathrm{a}}$ & $5.8^{\mathrm{b}}$ & $5.1^{\mathrm{b}}$ & $6.0^{b}$ \\
\hline & AK $10 \%$ & $6.5^{\mathrm{b}}$ & $5.9^{\mathrm{b}}$ & $5.9^{\mathrm{b}}$ & $5.9^{\mathrm{b}}$ & $5.4^{\mathrm{a}}$ & $5.2^{\mathrm{b}}$ & $6.0^{\mathrm{b}}$ \\
\hline \multirow{3}{*}{$6 \mathrm{M}$} & AK $0 \%$ & $6.4^{\mathrm{b}}$ & $4.9^{\mathrm{a}}$ & $5.3^{\mathrm{ab}}$ & 4.5 & $5.1^{\mathrm{ab}}$ & $4.0^{\mathrm{a}}$ & $4.9^{\mathrm{a}}$ \\
\hline & AK 5\% & $5.5^{\mathrm{a}}$ & $5.0^{\mathrm{a}}$ & $5.9^{\mathrm{b}}$ & 4.7 & $5.9^{\mathrm{b}}$ & $4.8^{b}$ & $6.1^{b}$ \\
\hline & AK $10 \%$ & $5.8^{\mathrm{ab}}$ & $6.3^{\mathrm{b}}$ & $4.9^{\mathrm{a}}$ & 4.9 & $4.6^{\mathrm{a}}$ & $4.8 \mathrm{~b}$ & $4.9^{\mathrm{a}}$ \\
\hline
\end{tabular}

${ }^{1)}$ AK $0 \%$, soy sauce (Kanjang) containing 0\% Astragalus membranaceus, AK 5\%, soy sauce (Kanjang) containing 5\% Astragalus membranaceus, AK 10\%, soy sauce (Kanjang) containing $10 \%$ Astragalus membranaceus.

${ }^{2)}$ During aging months.

${ }^{3)}$ Means with the different letters are significantly different $(\mathrm{p}<0.05)$ by Duncan's multiple range test.

\section{요 약}

본 연구에서는 기호성을 향상시킬 수 있는 고부가가치 간장을 개발하고자 황기 첨가량에 따른 간장의 이화학적 특성 및 관능평가를 실시하였다. 식염변화에서는 황기 $10 \%$ 첨가 간장에서 약간 감소하는 경향을 보였다. $\mathrm{pH}$ 변화는 실험군 모두 숙성기간에 따른 변화는 뚜렷하지 않았으며, 가용성 고형분 함량은 황기 $10 \%$ 첨가 간장를 제외하고 모두 2개월까지 급격히 증가되었으며 그 이후 일정한 양상 을 보였다. 그 반면 황기 $10 \%$ 첨가 간장는 숙성 초기에 증가되었지만 무첨가 및 황기 $5 \%$ 첨가 간장 보다 낮은 경향을 보였다. 갈색도 변화는 숙성이 진행될수록 증가되 는 경향을 보였으며 조단백질 함량은 무첨가 및 황기 $5 \%$ 첨가 간장은 숙성 기간이 지남에 따라 증가되는 경향을 보였지만 황기 $10 \%$ 첨가구는 숙성 기간에 따른 차이를

\section{감사의 글}

본 연구는 농촌진흥청 국립농업과학원 농업과학기술 연 구사업(과제번호 : PJ010122)의 지원에 의해 이루어진 것이 며 이에 감사드립니다.

\section{References}

1. Son KH, Lee HJ, Park HK, Park OJ (1998) Studies on taste compound content and read arch on condition of comsumer attitude to traditional Korean soy sauce with varing Meju type and fermentation jars. Korean J Food Sci, 14, 464-467

2. Cassidy A (1996) Physiological effects of phyto-estrogens in relation cancer and other human health risk. Proc Nutr 
Soc, 55, 399-471

3. Knight DC, Eden JA (1996) A review of the clinical effects of phytoestrogens. Obstet Gynecol, 87, 897-904

4. Kataoka S (2005) Functional effects of Japanese style fermented soy sauce and its compounds. J Biosci Bioeng, 100, 227-234

5. Lee HY, Cha YJ (2006) Isoflavone contents in soy sauce made with whole grain soybean Meju during fermentation. Korean J Food Nutr, 19, 460-465

6. Cho HY, Yang JL, Noh KH, Kim JJ, Kim YH, Huh KH, Song YS (2007) Anti-atherogenic effect of isoflavone through hypolipidemic, anti-oxidative and anti-inflammatory actions in C57BL/6 mice. Korean J Soc Food Sci Nutr, 36, 276-283

7. Oke M, Jissy K, Paliyath G (2010) Effect of soy lecithin in enhancing fruit juice/sauce quality. Food Res Int, 43, 234-240

8. Zang SE (2013) Isolation of antioxidant peptides from Korean traditional Ganjang fermented with Sterigmatomyces sp. and their inhibitory effect on human breast cancer cell viability. MS Thesis. Chonbuk National University, Korea, p 46-49

9. Baek NI, Kim YS, Kyung JS, Park KH (1996) Isolation of and hepatotoxic from the root of Astragalus membranceus. Korean J Pharmacogn, 27, 111-116

10. Inoue $\mathrm{K}$, Shirai $\mathrm{T}$, Ochiai H, Kasao M, Hayakawa $\mathrm{K}$, Kimura M (2003) Blood-pressure-lowering effect of a novel fermented milk containing $\gamma$-aminobutyric acid in mild hypertensives. European J Clin Nutr, 57, 490-495

11. Jung HS, Lee EJ, Kim JS, Kang SS (2008) Phytochemical studies on Astragalus membranceus root (3) : triterpenoids and sterols. Korean J Pharmacogn, 39, 186-193

12. Ryu MS, Kim EH, Chun MS, Kang SH, Shim BS, Yu YB, Jeong GJ, Lee JS (2008) Astragali Radix elicits anti-inflammation via activation of MKP-a, concomitant with attenuation of p38 and Erk. J Ethnopharmacol, 115, 184-193

13. Park HR, Lee MS, Jo SY, Won HJ, Lee HS, Lee H, Shin KS (2012) Immuno-stimulating activities of polysaccharides isolated from commercial soy sauce and traditional Korean soy sauce. Korean J Food Sci Technol, 44, 228-234

14. Ko YJ, Lee GR, Ryu CH (2013) Anti-inflammatory effect of polysaccharide derived from commercial Kanjang on mast cells. J Life Sci, 23, 569-577

15. Lee MS, Shin KS (2014) Intestinal immune-modulating activities of polysaccharides isolated from commercial and traditional Korean soy sauces. Korean J Soc Food Sci Nutr, 43, 9-15

16. Lee YJ, Chung KH (2004) A study on a morphological identification of Astragalus root. Korean J Herbology, 19, 61-68

17. Sin JM (1988) Bangyak Habpyon explanation. Sungbosa, Korea, p 81

18. Lee HY, Ha HK, Jang DY, Choi JY, Lee NH, Ma JY, Yu YB, Shin HK (2008) Study on pharmacological activity of sipjeondaebotang by difference in component ratio between Astragali radix and Cinnamomi cortex. Korean J Oriental Med Soc, 29, 156-166

19. Kitagawa I, Wang HK, Saito M, Yoshikawa M (1983) Saponin and sapogenol XXXVI. Chemical constituents of Astragali radix, the root of Astragalus membranaceus Bunge (3) Astragalosides Ш, V, and VI. Chem Pharm Bull, 31, 709-715

20. Kitagawa I, Wang HK, Yoshikawa M (1983) Saponin and sapogenol XXXVII. Chemical constituents of Astragali radix, the root of Astragalus membranaceus Bunge (4) Astragalosides VII, and VII. Chem Pharm Bull, 31, 716-722

21. Hirotani M, Zhou Y, Rui H, Furuya T (1994) Cycloartane triterpene glycosides from the hairy root cultures of Astragalus mongholicus. Phytochem, 37, 1403-1407

22. Zhou YM, Hirotani HR, Furuya T (1995) Two triglycoside triterpene Astragalosides from the hairy root cultures of Astragalus mongholicus. Phytochem, 38, $1407-1410$

23. Choi HS, Joo SJ, Yoon HS, Kim KS, Song IG, Min KB (2007) Quality characteristic of Hwangki (Astragalus membranaceus) Chungkukjang during fermentation. Korean J Food Preserv, 7, 297-302

24. Min SH (2006) Quality characteristics of Doenjang containing Astragalus membranaceus water extracts. Korean J Food Cookery Sci, 22, 514-520

25. Oh HS, Kim JH (2006) Development of functional soy-based stew sauce including hot water extract of Cornus officinalis S. et Z. Korean J Food Culture, 21, 550-558

26. Oh JY, Kim YS, Shin DH (2002) Changes in physicochemical characteristics of low - salted Kochujang with natural preservatives during fermentation. Korean J Food Sci Technol, 34, 835-841

27. Sato M, Ramarathnam N, Suzuki Y, Ohkubo T, Takeuchi M, Ochi H (1996) Varietal differences in the phenolic 
content and superoxide radical scavenging potential of wines from different sources. J Agric Food Chem, 44, $37-41$

28. Sin HS (1987) Food Analysis. Sinkwang publishng Co., Seoul, Korea. p 70-83

29. Kwon OJ, Kim MA, Kim TW, Kim DG, Son DH, Choi UK, Lee SH (2010) Changes in the quality characteristics of soy sauce made with salts obtained from deep ocean water. Korean J Food Preserv, 17, 820-825

30. Chung HS, Ji GE (1996) Composition and functionality of Chonma. Korean J Food Sci Technol, 28, 53-57

31. Kim YA, Kim HS, Chung MJ (1996) Physicohemical analysis of Korean traditional soy sauce and commercial soy sauce. Korean J Soc Food Sci, 12, 273-279

32. Kim YS, Yeom DM, No SB, Kim YH, Jeong SK(2008) Quality characteristics of soybean anchovy sauce added with medicinal herbs. Korean J Food Preserv, 15, 367-376

33. Kwon SH, Choi JH, Ko YR, Shon MY, Park SK (2003) Changes in free sugars, organic acids and fatty acid composition of Kanjang prepard with different cooking conditions of whole black bean. Korean J Food Preserv, 10, 333-338

34. Choi JD, Im MH, Chung HC, Lee CW, Kim YH, Choi C, Choi KS (1997) The effect of mashing and maturing conditions on the quality of Korean traditional Kanjang (soy sauce). Agric Chem Biotechnol, 40, 365-368

35. Rural Development Administration (2011) Standard food composition table, $8^{\text {th }}$ ed, National academy of agricultural science, Suwon, Korea, p 460
36. Kim JG (2004) Changes of components affecting organoleptic quality during the ripening of Korean traditional soy sauce-amino nitrogen, amino acids, and color. Korean J Env Hlth, 30, 22-28

37. Jeong SJ, Shin MJ, Jeong SY, Yang HJ, Jeong DY (2014) Characteristic analysis and production of short-ripened Korean traditional soy sauce added with rice bran. Korean J Soc Food Sci Nutr, 43, 550-556

38. Lee CH (1973) Studies on the amino acid composition of Korean fermented soybean Meju products and the evaluation of the protein quality. Korean J Food Sci Technol, 5, 210-214

39. Kim YA, Kim HS, Chung MJ (1996) Physicohemical analysis of Korean traditional soy sauce and commercial soy sauce. Korean J Soc Food Sci, 12, 273-279

40. Park HK, Sohn KH (1997) Analysis of significant factors in the flavor of traditional Korean soy sauce (П) analysis of nitrogen compounds, free amino acids and nucleotides and their related compounds. Korean J Dietary Culture, 12, 63-69

41. Kim MJ, Rhee HS (1990) Studies on the changes of taste compounds during soy paste fermentation. Korean J Soc Food Sci, 6, 1-8

42. Kim YS, Shin DB, Koo MS, Oh HI (1994) Changes in nitrogen compounds of traditional kochujang during fermentation. Korean J Food Sci Technol, 26, 389-392

43. Hwang JB, Yang MO, Shin HY (1998) Survey for amino acid of medicinal herbs. Korean J Food Sci Technol, 30, $35-41$ 